\title{
Designing The Information System for Data Collection of Covid-19 Symptoms for Indonesian Citizens
}

\author{
Thamrin ${ }^{*}$, Delsina Faiza ${ }^{2}$, Ahmaddul Hadi ${ }^{3}$, Khairi Budayawan', Geovanne Farell5, Igor Novid6 \\ 1,2,3,4,5,6 Faculty of Engineering, Universitas Negeri Padang, Indonesia \\ *Corresponding Author: thamrin elka@ft.unp.ac.id
}

\begin{abstract}
INTISARI
Sistem informasi merupakan hasil dari perkembangan teknologi yang sangat cepat berkembang, karena kebutuhan manusia sebagai pengguna teknologi terhadap informasi yang sangat tinggi dan cepat. Dimulai dari perkembangan teknologi komputer yang sangat cepat, sehingga komputer memiliki ukuran yang kecil seperti ponsel pintar, tablet, laptop, dan lainnya. Perangkat komputer yang kecil ini harus terhubung dengan Internet sehingga bisa dimanfaatkan dengan baik. Dan ketika perangkat komputer tersebut terhubung dengan Internet, maka sistem informasi memainkan perannya sebagai penyedia informasi yang ingin diakses oleh pengguna komputer tersebut. Sistem informasi yang dikembangkan pada makalah ini adalah Sistem Informasi Pendataan Warga, sistem ini dibuat dengan menggunakan kerangka kerja YII. Kerangka kerja YII menggunakan metode Model, View, Controller (MVC) yang memudahkan dalam mengembangkan Sistem Informasi Pendataan Warga. Dengan adanya Sistem Informasi ini, maka informasi mengenai kondisi terbaru dari warga dapat dengan mudah diakses. Sehingga pihak Kelurahan, Kecamatan, Rukun Warga (RW), dan Rukun Tetangga (RT) akan memiliki informasi terbaru mengenai warganya dan mudah melakukan antisipasi apabila dibutuhkan. Dalam pengembangan sistem ini, memiliki tahapan seperti studi pustaka, observasi, wawancara, analisis, perancangan, uji coba dan implementasi. Kesimpulan yang didapatkan adalah sistem informasi ini mampu melaksanakan fungsi yang diinginkan ketika setelah diimplementasikan.
\end{abstract}

Kata kunci: Framework YII, MVC, Pendataan Warga, Sistem Informasi

\begin{abstract}
Information systems are the result of rapid technological development, because the needs of humans as information users of technology are very powerful and rapid. Begin with the very rapid growth of computer technology, computers such as smartphones, tablets, laptop and others are limited in scale. This small computer device must be connected to the Internet so that it can be used properly. And the information system plays its role as a provider of information that computer users want to access when the computer device is linked to the Internet. The information system developed in this paper is the Citizen Data Collection Information System, this system was created using the YII Framework. The YII framework uses the Model, View, Controller (MVC) method which makes it easier to develop a Citizen Data Collection Information System. With this Information System, information about the latest condition of the residents can be easily accessed. So that the Sub-district, District, Rukun Warga (RW), and Rukun Tetangga (RT) will have the latest information about their residents and easily anticipate if needed. In the development of this system, it has staged such as literature study, observation, interviews, analysis, design, testing, and implementation. The conclusion is that this information system can carry out the desired function when it is implemented.
\end{abstract}

Keywords: Citizen Data, Information System, MVC, YII Framework 


\section{INTRODUCTION}

Information systems have developed very rapidly along with the development of communication technology, especially the Internet. With the advent of the Internet, human information needs are easier to fulfill [1]. One way to meet these needs is to use an information system accessed using the Internet. One of the information system applications is a website that can provide the information needed by humans.

Websites can be created using HTML, ASP, AJAX, and PHP programming languages, and most website developers combine HTML, AJAX, and PHP programming languages [2]. This merger is done because the HTML programming language is not able to make a website dynamic, and this deficiency is covered by others. For a website to function properly, a database management system (DBMS) is needed. One of the most widely used DMS applications is MySQL, and this application can make a website more dynamic and multifunctional [3].

The process of making a website can be done more easily by using 2 (two) ways [4], namely:

1. Native, according to the name which means original. Pure website development is written by programmers and uses additional arrangements made by other programmers. This native website development will greatly assist programmers in understanding the use and integration of the HTML, AJAX, CSS, and PHP programming languages as well as for MySQL applications.

2. The framework, which means a structured application. The framework is a collection of scripts and functions designed to make it easier for programmers to create and develop websites. Knowledge and understanding of the programming language used on a website are needed so that the use of the framework is carried out properly. By using a framework, the process of creating and developing a website can be done together [4].

Framework development is fast, and many have been released [5]. Some examples of frameworks are:

1. Yii

2. Zend Framework

3. CodeIgniter

4. Laravel

5. Symfony
6. CakePHP

7. Dll

This article presents the process of implementing a framework in an information system application that is made. The framework used is the Yii2 framework, this is because the Yii2 framework has the advantage of being very light and has a better caching mechanism [6].

\section{METHOD}

This citizen data collection information system was created using the Waterfall method [7]. The stages of this method are requirements analysis, system design, implementation, and testing [7], [8]. Meanwhile, the framework used is the Yii2 framework which adopts the model-viewcontroller (MVC) pattern [9]. An overview of the information system created can be seen in Figure 1.

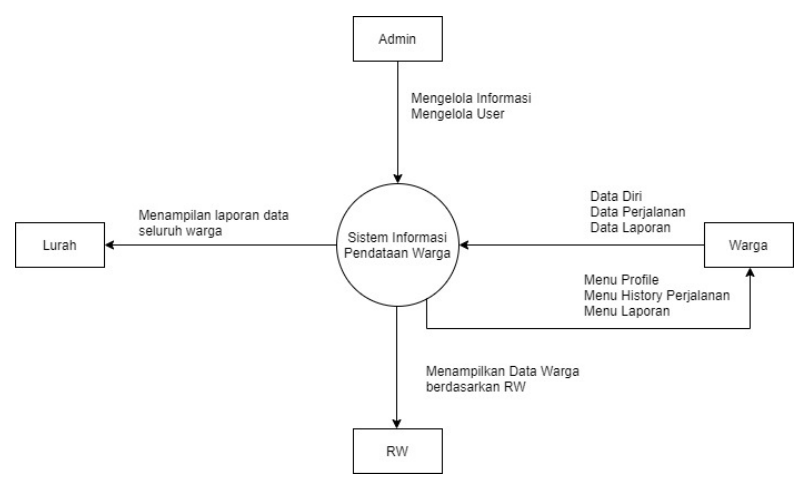

Figure 1. Database Mirroring Architecture

\section{Requirements Analysis}

The collection of the parts of the software is done at this stage. All requirements, both functional and non-functional, are collected at this stage. So that the needs that have been collected can be specified and applied later.

It is possible to categorize processes carried out by information systems as functional requirements. And the patterns of behavior of information systems fall into the non-functional requirement group. It is followed by the second stage of the Waterfall method after the needs are obtained, analyzed, and grouped.

\section{Designing of the System}

The created information system is designed for object-based programming using UML diagrams that serve as a communication and visualization medium for those involved in the development of the information system [10], [11], [12]. The types of 
UML diagrams used are use-case diagrams and class diagrams. In the Use-Case Diagram, the functionality of the information system will be displayed, and the data required by the system will then be grouped into classes, which is a function of the class diagram.

In addition to designing using UML, the design of the information system's menu structure is also carried out at this stage. The interface shape of the information system will be determined by the menu structure design. An interface that is efficient and easy to understand will be able to provide a good information system [10], [11], [12].

\section{Implementation}

According to the Yii2 framework used, the system design results developed in the previous stage are enforced. The implementation mechanism of this method should follow the rules and structure listed in the Yii2 framework. There are three main directories in the Yii2 system and, according to the pattern it adopts [13], [14]. These are the directories:

1. Models Directory

Has functions as directed by the controller in arranging, planning, manipulating, and organizing data (from the database).

2. Views Directory

It helps to present information to the user (which is easy to understand) according to the controller's instructions.

3. Controllers Directory

It has a part in influencing what the model can do and views based on user requests. Often, however, demands from the consumer do not necessarily enable the model to take action. Like showing the User Registration form tab.

\section{Evaluation}

Citizen data collection information system assessment utilizes 2 (two) approaches, namely:

1. Black-box Method

This approach aims to assess the system's efficiency so that the system's flaws and weaknesses can be identified. Based on the results of testing using this process, it can be seen if the system operated according to the design that was developed [15].

2. User Acceptance Method

The aim of this approach is to promote users' access and comprehension of the purpose of the information system. Through testing with this technique, it is simple for users to get the necessary data [16].

\section{RESULTS AND DISCUSSION}

In this section, the outcomes and discussion of each stage using the Waterfall method will be addressed.

\section{Requirements Analysis Results}

The needs of a citizen data collection information system focused on the individual are:

1. Admin

2. Mayor, can access all citizens who are in the city he leads.

3. The district head, can access all residents in the district he leads, as well as data on residents in the city where the sub-district is located.

4. The sub-district can access all residents in the sub-district he leads, as well as the data on residents in the District and City where the Subdistrict is located.

5. RW, is able to access all residents who are in the RW they lead, as well as data on residents in the Sub-district, District, and City where the RW is located.

6. RT, is able to access all residents who are in the RT they lead, as well as data on residents of the RT, Sub-district, District, and City where the RT is located.

7. The Head of the Family, can see the data of residents who have the same Family Card number.

The need for a software system to create a citizen data collection information system is: $\mathrm{XAMPP}$, as a local server before going online, to run information systems; Visual Studio Code, as a text editor for the code that need to be created; Yii2 Framework version 2.0.34; Web browser.

\section{Designing of the System Results}

The system design outcomes are in the form of use-case diagrams, class diagrams, and the design of the citizen data collection information system's initial display. A Use-Case Diagram displays Figure 3 , which provides the functional specifications of an information system. 


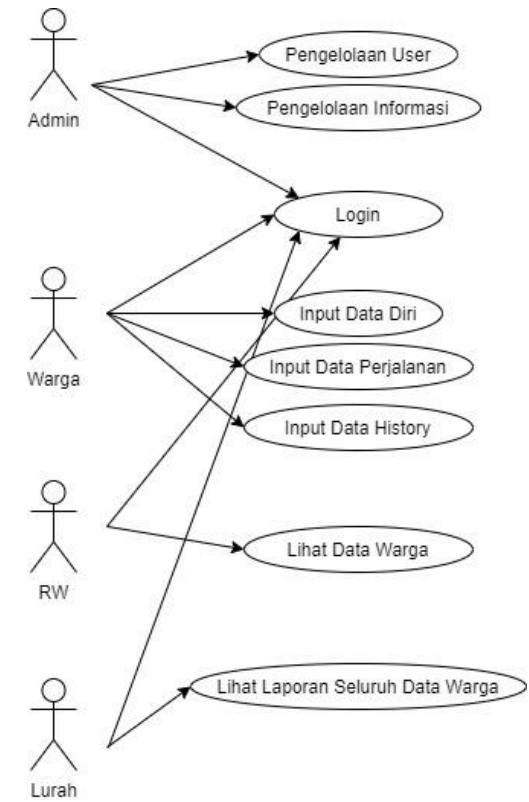

Figure 2. Use Case Diagram

\section{Implementation Results}

The information system implemented using the Yii2 framework has a display as shown in Figure 4.

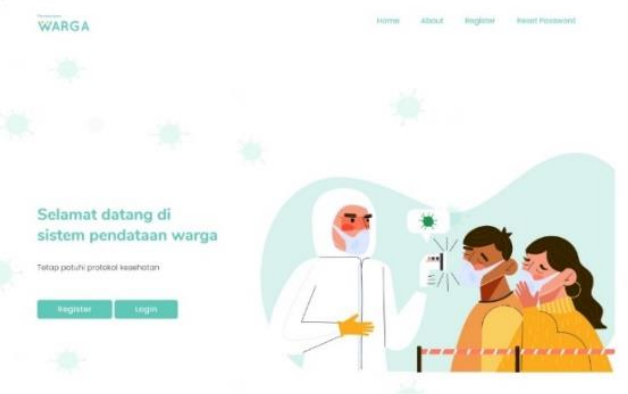

Figure 4. Home page of the information system

The application interface of the citizen data collection information system can be seen in Figure 5 after signing in.

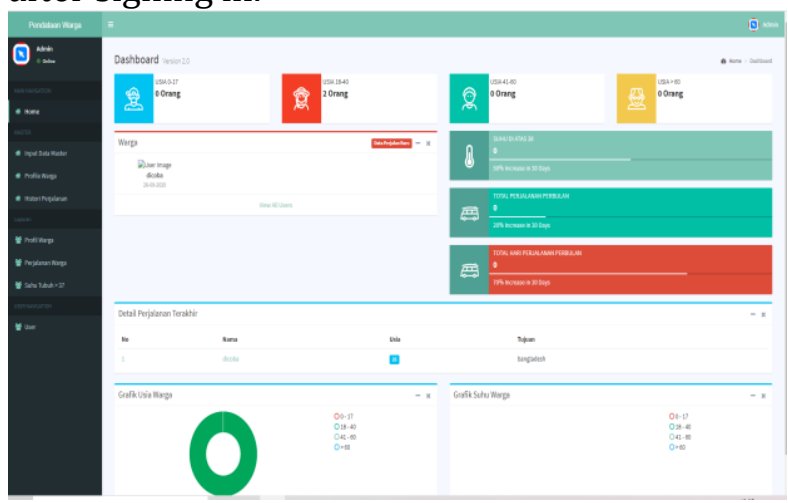

Figure 5. Admin page of the information system
In the picture above, when the program is accessed as an admin, this is the interface. You can see the data of people who have been grouped by age in this GUI. Similarly, temperature-based results, monthly citizenship trips, and regular citizenship trips. On daily citizen trips, in red, since it increased to $70 \%$ for citizen trips.

The application interface will be shown in Figure 6 if those who log in are residents.

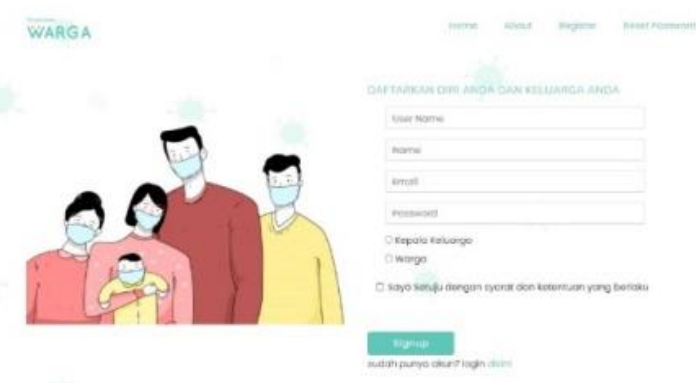

Figure 6. Citizen page of the information system

Only the head of the family is can make a registration. Only one account is issued to each family card to report on the travel scheme carried out for all family's members. The data that entered by the residents is possible to see by the head of the family and send the report to the system admin.

\section{Evaluation Results}

System evaluation is carried out using the methodology of Black-Box and User Acceptance. The key feature of the device being evaluated in the Black-Box method is the citizens' feedback report and the report's printed tab. By logging in using admin data, data is collected in compliance with the results that have been entered as in Figure 7 when monitoring the citizen input report page. Similarly, it can also be done correctly when printing reports as can be seen in Figure 8.
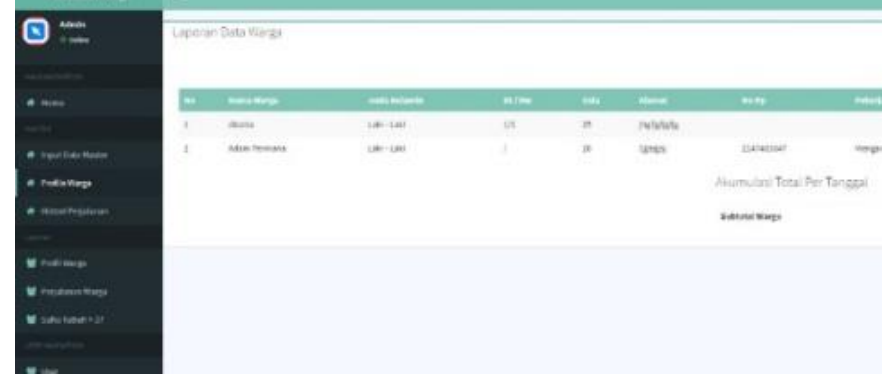

Figure 7. Citizen condition report page 


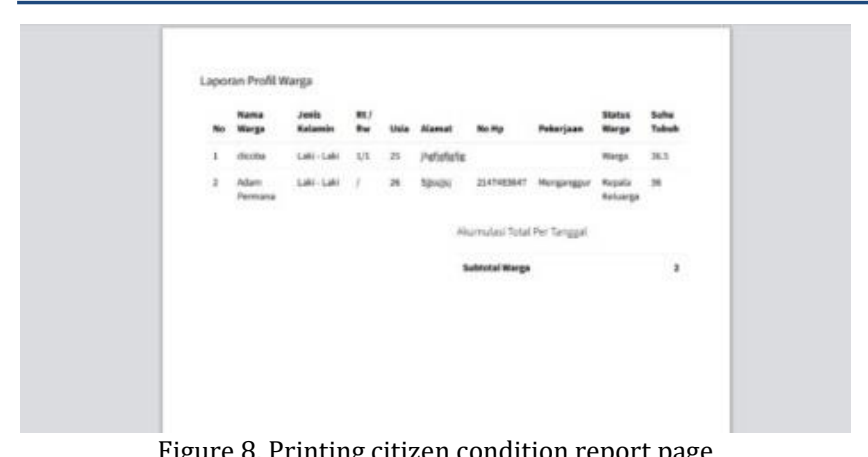

Figure 8. Printing citizen condition report page

40 residents were then asked to view and enter data using the User Acceptance system for research. Residents are asked to fill out a questionnaire of 10 questions about the information system that has been used since residents have accessed it. You can see the outcomes of the questionnaire in table 1.

\begin{tabular}{lll}
\multicolumn{2}{l}{ Table 1. The results of the questionnaire } \\
\hline Answer criteria & Number of Respondents & Score \\
\hline Very Good (VG) & 23 & 115 \\
Good (G) & 15 & 60 \\
Average (AV) & 2 & 6 \\
Less Good (LG) & 0 & 0 \\
Not Good (NG) & 0 & 0 \\
\hline
\end{tabular}

Score interpretation

$$
\begin{aligned}
& \text { Score } \quad=(\text { Number of VG } * 5)+(\text { Number of } \\
& \mathrm{G} * 4)+(\text { Number of } \mathrm{AV} * 3)+ \\
& (\text { Number of } L G * 2)+(\text { Number of } \\
& \left.\mathrm{NG}^{*} 1\right) \\
& =(23 * 5)+(15 * 4)+(2 * 3)+(0 * \\
& \text { 2) }+(0 * 1) \\
& =115+60+6 \\
& =181 \\
& =(181 / 200) * 100 \% \\
& =90.5 \%
\end{aligned}
$$

\section{CONCLUSION}

Based on the results of the Black-Box process, the citizen data collection information system generated using the Yii2 framework has a purpose according to the plan. The percentage of the User Approval process is 90.5 percent, which is means that this information system is well received by users.

\section{BIBLIOGRAPHY}

[1] I. Novid, D. Faiza and Thamrin, "Analisa Perbandingan Routing Protokol pada Wireless Sensor Networks (WSNs)," Jurnal Vokasional
Teknik Elektronika dan Informatika, vol. 7, no. 3, 2019.

[2] A. B. Warsito, M. Yusup and Yulianto, "Kajian Yii Framework dalam Pengembangan Website Perguruan Tinggi," CCIT Journal, vol. 7, no. 3, pp. 437-451, 2014.

[3] D. Aryani, Q. Aini and T. Novelia, "Perancangan Pen+ menggunakan Metode Yii Framework pada Perguruan Tinggi Raharja," Journal Sensi: Strategic of Education in Information System, vol. 3, no. 1, pp. 46-61, 2017.

[4] E. Febriyanto, I. Handayani and D. Suprayogi, "Aplikasi Sistem Penilaian Penguji berbasis Yii Framework sebagai Media Input Nilai Sidang Tugas Akhir dan Skripsi pada Perguruan Tinggi," CSRID Journal, vol. 10, no. 2, 2018.

[5] A. Zurkiewicz and M. Miłosz, "Selecting A Php Framework For A Web Application Project The Method And Case Study," in Conference: 9th International Technology, Education and Development Conference (INTED2015), Madrit, 2015.

[6] L. Ullman, The Yii Book, Chicago: Larry Ullman Press, 2017.

[7] W. W. Royce, "Managing the Development of Large Software Systems," in IEEE WESCON, New York, 1970.

[8] R. S. Pressman, Software Engineering: a Practitioner Approach, Chicago: McGraw-Hill Education, 2015.

[9] G. Farell, H. K. Saputra and I. Novid, "Rancang Bangun Sistem Informasi Pengarsipan Surat Menyurat (Studi Kasus Fakultas Teknik Unp)," Jurnal Teknologi Informasi dan Pendidikan, vol. 11, no. 2, pp. 55-62, 2018.

[10] J. M. Chonoles and J. A. Schardt, UML 2 for Dummies, Wiley Publishing, 2003.

[11] M. Flower, UML Distilled: A Brief Guide to the Standard Object Modelling Language, Addison-Wesley, 2004.

[12] H. Tohari, Analisis Serta Perancangan Sistem Informasi Melalui Pendekatan UML, Yogyakarta: Andi, 2014.

[13] B. Keck, Yii 2 for Beginners, Leanpub, 2014.

[14] A. Bogdanov and D. Eliseev, Yii2 Application Development Cookbook - Third Edition, Packt Publishing, 2016.

[15] R. Guidotti, A. Monreale, F. Turini, D. Pedreschi and F. Giannotti, "A Survey of Methods for 
Explaining Black Box Models," ACM Computing Surveys, vol. 51, no. 1, pp. 1-45, 2018.

[16] E. Wahdain and M. N. Ahmad, "User Acceptance of Information Technology: Factors, Theories and Applications," Journal of Information Systems Research and Innovation, vol. 6, no. 1, pp. 17-25, 2014. 